\title{
Reading the Bible again with Marcus Borg
}

\author{
Flip (P J W) Schutte (Witbank) \\ Department of New Testament Studies \\ University of Pretoria
}

\begin{abstract}
This article focuses on Marcus $J$ Borg's book "Reading the Bible again for the first time" with the all important subtitle "Taking the Bible seriously but not literally." He offers a new understanding of Scripture that respects both tradition and reality, blending biblical scholarship with a concern for authentic faith. This article presents a synopsis of the contents of Borg's book, together with remarks, additions and even includes contradictory viewpoints from other contemporary scholars, which are being included not with the purpose of taking sides, but to stimulate conversation on Bible reading, a burning issue of our times.
\end{abstract}

\section{INTRODUCTION}

Marcus $\mathrm{J}$ Borg is well known for the contributions he has made to historical Jesus studies. He is professor of Religion and Culture at Oregon State University and is the author of the best-selling Meeting Jesus again for the first time; The God we never knew; and Jesus: A new vision. His Reading the Bible again for the first time, with the subtitle Taking the Bible seriously but not literally, deserves more than just a review and it is therefore the aim of this article to put the book on the table and to engage in conversation with it. Part one which he called Foundations and part three The New Testamen will be discussed. For the purpose of this article, part two on The Hebrew Bible will not be included.

What makes this book of the utmost interest in current times, is the fact that many inside and outside organized religion are searching for an enlightened and contemporary way in which to be believers and to appreciate the profound richness of the Bible. In his book, Borg presents a new understanding of scripture that respects both tradition and reality. He, like most South African New Testament scholars, lives in two communities,

\footnotetext{
${ }^{1}$ Dr P J W Schutte (D Litt et Phil, DTh) is a PhD student in the Department of New Testament Studies at the Faculty of Theology, University of Pretoria.
} 


\section{Reading the Bible again with Borg}

namely the academic community of biblical scholarship and the religious community of the church (and is aware of the tension that sometimes arises between the two). Borg has committed his life to God within the Christian tradition, and he has sought to explore the religious significance of the Bible for Christians. This has led to a way of reading the Bible from a historicalmetaphorical point of view, which means that the Bible is taken seriously, without being taken literally.

\section{READING LENSES}

As stated above, one of the most imperative needs in our time is to find a way of reading the Bible anew. As reading and seeing go together, how we see, affects how we read, according to Borg (2002:3). The older way of seeing and reading the Bible has made it irrelevant and implausible to vast numbers of people. In the approach to how the Bible is read, two conflicting groups distinguish themselves, namely the fundamentalists and the moderate-toliberal Christians. For the fundamentalists the Bible is the inerrant and infallible Word of God. The second group of readers are convinced that they cannot take the Bible literally. However, they are less clear about how they do see the Bible than about how they do not see it (Borg 2002:5).

The older way of seeing the Bible has been termed "natural literalism" (Borg 2002:8). This means that the Bible is read and accepted literally without effort. Natural literalism is different from "conscious literalism." This is a modern form of literalism which is aware of problems posed by a literal reading of the Bible, but insists upon it nevertheless. Whereas naturalism is effortless, conscious literalism implies effort in the sense that it requires faith to believe the things that are hard to believe. Many Christians, even Biblical scholars and theological professors in South Africa still read the Bible in this way. Unbelievable, but true!

According to Borg (2002:9) their views on the Bible are that it is a (1) divine product, (2) therefore it is true and authoritative, and (3) it is historically and factually true. They speak of the Bible as the "Word of God." How one sees the Bible and how one sees Christianity go hand in hand. This older way of seeing Christianity was (1) literalistic, (2) doctrinal, (3) moralistic, implying that a Christian must try to be good and to live according to the law of God. But because we are not very good, this form of Christianity was centered on the dynamic of sin, guilt, and forgiveness. The older way was (4) patriarchal, (5) built on exclusivity, and (6) afterlife-oriented (Borg 2002:11-12). Dramatic movements are taking place in our churches at the moment. People don't read the Bible and come to church for the same reasons they once did. People don't worship like they used to. People don't have the same loyalties, 
the same devotions, or the same sense of spirituality (Woods 1996:5). A new way of reading is thus unavoidable!

Today we are aware of (1) religious pluralism. Thus many of us find the claims to exclusivity of the Christian tradition impossible to accept. We are also aware of (2) historical and cultural relativity, and we are (3) modern people. Modernity is characterized by scientific ways of knowing and by the Newtonian worldview. It has made us skeptical about the spiritual reality, and it has led us to be preoccupied with factuality. We also live on the boundary of (4) postmodernity. Postmodernity is marked by the realization that modernity itself is a culturally conditioned, relative construction; it is marked by a turn to experience, and by a movement beyond fact fundamentalism to the realization that stories can be true without being literally and factually true (Borg 2002:1317).

Living in this world of multicultural awareness has put tremendous pressure on the Christian vision and myth. According to Mack (1995:308) Christians have to be honest and critical about their own tradition as well. We must remember that the New Testament was not written by eyewitnesses of an overpowering divine appearance in the midst of human history, the impression created by the final formation of the New Testament. It is however not so.

Given who we have become, one of the imperative needs of our time, according to Borg (2002:18) is a re-visioning of the Bible and Christianity. What is needed is a way of seeing the Bible that is serious about the important and legitimate ways in which we differ from our ancestors. Being Christian is not about believing in the Bible or in Christianity, but it is about a deepening relationship with the God to whom the Bible points, lived within the Christian tradition as a sacrament of the sacred (Borg 2002:18).

The key that is needed to read the Bible and to unlock the meaning of its texts, is critical scholarship. A church that adores the Bible but ignores biblical scholarship is a house built on sand. The church must take seriously what scholars today are saying, especially about the Jesus tradition (Patterson 1998:xiii).

One must take the mythological character of the Bible seriously, and as Mack (1995:309) pointed out, we must also remember that myth making never completely starts from scratch. It is born both of new ideas and of the rearranging of traditional images already at hand. Thus, we must recognize that previous/past reasons for telling stories are not good enough to be our reasons for continuing to tell the stories just as previous generations told them. On this score, Mack is far more straight forward than Borg. 


\section{THE BIBLE AS A HUMAN CONSTRUCTION}

A decision about how one sees its origin, is key to reading the Bible. By seeing the Bible as a human product does not deny the reality of God. God is real and can be experienced (Borg 2002:22). Borg sees the Bible as the response of two ancient communities to their experience of God. It is a human product, though generated in response to God. "As such, it contains ancient Israel's perceptions and misperceptions of what life with God involves, just as it contains the early Christian movement's perceptions and misperceptions" (Borg 2002:27). According to Borg the Bible does not come with footnotes that say, "This passage reflects the will of God; the next passage does not," or "This passage is valid for all time; the previous passage is not."

Though the Bible is a human product, it is also sacred to three religious traditions. The process whereby the Bible became sacred is known as "canonization." According to Goody (1998:3) canonization can be understood as the procedure whereby human action becomes institutionalized, authoritative, and recognized as canonical. To speak of the Bible as sacred does not address its origin, according to Borg (2002:29), but its status within a religious community. This also leads to a different way of seeing the authority of the Bible. To be Christian means to live within the world created by the Bible.

We listen to it well and let its central stories shape our vision of God, our identity, and our sense of what faithfulness to God means. It is to shape our imagination, that part of our psyches in which our foundational images of reality and life reside. We are to be a community shaped by scripture. The purpose of our continuing dialogue with the Bible as sacred scripture is nothing less than that.

(Borg 2002:31)

The function of the Bible is thus the shaping of Christian vision and identity. In that sense the Bible is a sacrament of God with sacrament in this instance meaning a vehicle by which God becomes present and a means through which the Spirit is experienced.

Virtually anything can become sacramental: nature, music, prayer, birth, death, sexuality, poetry, persons, pilgrimage, even participation in sports, and so forth. Things are sacramental when they become occasions for the experience of God, moments when the Spirit becomes present, times when the sacred becomes an experiential reality.

(Borg 2002:31) 
It seems that Borg would agree with me when I state that the purpose of reading the Bible is not to read the "Word of God," but to listen for the Spirit of God speaking through the words of the biblical text. By calling the Bible the Word of God reference is therefore not made to its origin, but to its status and function in a community, maybe even to the experience created by reading it!

According to Borg (2002:34) the Bible is like a finger pointing to the moon. One must not believe in the finger, but in that to which the finger points. The Bible is also a lens through which we see God. There is a crucial difference between believing in the lens and using the lens as a way of seeing that which is beyond the lens.

Being Christian is about a relationship with the God who is mediated by the Christian tradition (and scriptures) as a sacrament. To be Christian is to live within the Christian tradition as a sacrament and to let it do its transforming work within and among us (Borg 2002:35).

The implications of reading the Bible from this point of view are enriching. What it signifies to me is that there is no direct speech in the Bible from God himself. What we have are witnesses of how people had experienced God and what they believed God would have said in that given context. The content of the Bible is thus tied to a specific context. The metaphors, language, even the type of message are bound to a specific time and place in history. That is why Christians should learn to quote verses from scripture with caution. Perhaps the charismatic Christians and the fundamentalists are those who most need to read this book.

\section{HERMENEUTICS IS THE KEY}

The "historical" approach refers to all the methods that are relevant to discerning the ancient historical meanings of biblical texts. This historical approach for Crossan (1995:199) is an analysis of which the theories and methods, evidence and arguments, results and conclusions are open, in principle and practice to any human observer, any disciplined investigator, any self-conscious and self-critical student. It is about the question: "What did this text mean in the ancient historical setting in which it was written?" It thus focuses on the historical illumination of a text in its ancient context (Borg 2002:38). This process is indispensable for genuinely experiencing the Bible as a collection of documents from the past.

The metaphorical approach enables us to see and affirm meaning that goes beyond the particularity of what the text meant in its ancient setting. It asks the question: "What does this story mean as a story, independent of its historical factuality?" A metaphorical approach to the Bible thus emphasizes 


\section{Reading the Bible again with Borg}

metaphors and their associations. "It emphasizes seeing, not believing. The point is not to believe in a metaphor, but to see in light of it" (Borg 2002:41).

A metaphor can be profoundly true. The Bible is a combination of history and metaphor, or as Borg (2002:45) puts it: "... the Bible is a combination of historical memories and metaphorical narratives."

A metaphorical narrative is a story that combines both history and metaphor. It results in what Borg (2002:45) calls "history metaphorized." A historical event lies behind the story, but the way in which the story is told, gives the narrative a metaphorical meaning as well (the story in Mark about healing the blind being a case in point). Then there are those stories which are purely narrative (Jesus' birth; walking on the water; multiplying loaves and fishes; changing water into wine being examples of such). "The recognition that the Bible contains both history and metaphor has an immediate implication: the ancient communities that produced the Bible often metaphorized their history. This is indeed the way in which they invested their stories with meaning. But we, especially in the modern period, often have historicized their metaphors ... they often mythologized history ..., while we have tended to literalize their mythology. And when one literalizes metaphor or myth, the result is nonsense" (Borg 2002:47). When one recognizes a metaphorical narrative as such, the result is a powerful story. With this statement Borg pinpointed the exact problem that so many readers today experience with the traditional way of understanding the Bible.

For modern readers (like myself) it is impossible to believe that the biblical narratives are history. One has to sacrifice one's logic and intellect if one wants to read the Bible as history. To read it as literature, as myth, as message, is a much more rewarding and enriching experience.

The stories in the Bible are not just about the divine-human relationship in the past, it is also about the present. According to Borg (2002:48) the way the exodus story is used in the Jewish celebration of Passover each year illustrates this claim. It said: "It was not just our fathers and our mothers who were Pharaoh's slaves in Egypt, but we, all of us gathered here tonight ..." Thus, the exodus story is understood to be true in every generation. It portrays bondage as a perennial human problem and proclaimed God's will that we be liberated from bondage. It is thus about us and God (Borg 2002:49). What it means to me is that by reading the stories as non-history, one can have a timeless interaction in faith with God.

Contemporary readers of the Bible have a serious need to move from precritical naiveté (we simply hear the Bible's stories as true stories) through critical thinking (concerned with factuality) to postcritical naiveté (the ability to once again hear the biblical stories as true stories, even knowing that they 
may not be factually true and that their truth does not depend on their factuality) (Borg 2002:50).

Postcritical naiveté is not a return to precritical naiveté. It includes critical thinking with it. It does not reject the insights of historical criticism, but integrates them into a larger whole. One realizes that the truth of the story lies in its metaphorical meaning (Borg 2002:51). In a sense I think one could call this process a process of "decanonization." Canonicity implies the assignment of high, or ultimate authority to a specific set of writings and decanonization refers to a gradual process of invalidation of that set of writings (Adriaanse 1998:314), not to destroy the texts or their authority, but to open them up to critical investigation, and to open them up for a new way of reading and understanding.

With Borg's Foundations as a point of departure, one can move on to his perception regarding the origin of the New Testament.

\section{THE GENESIS OF THE JESUS TRADITION}

Both Jesus and his early followers were Jewish and they saw themselves as doing something within Judaism, "not as founding a religion separate from Judaism. Paul did not regard himself as converting to a new religion, but saw himself as a Jew all of his life. Most (and perhaps all) of the authors of the New Testament were Jewish. The word 'Christianity' does not occur in the New Testament” (Borg 2002:186). Thus, early Christianity is best understood when seen as a way of being Jewish.

The first century was a restive and violent time. There was the institutional and structural violence of Herodian and Roman rule, there was the violence of social bandits and groups and there was the violence of armed revolutionary movements. In $4 \mathrm{BCE}$, when Herod died, armed revolts erupted in most parts of the kingdom, including Galilee. The Romans conquered Israel and destroyed the temple in $70 \mathrm{CE}$. With the destruction of the temple, Jewish sacrificial worship ceased and Judaism changed forever (Borg 2002:188).

Where the Hebrew Bible was written over a period of eight hundred years, the New Testament was written in one hundred years or less, and was the literature of a sectarian movement numbering only a few thousand people (Borg 2002:188). Mack (1995:6) wouldn't call it a movement as Borg did. He argues that there were different responses to the teachings of Jesus. Some responses were of the type we call Jesus movements, others became congregations, while others developed into enclaves for the cultivation of spiritual enlightenment. And they all competed in their claim to be the true followers of Jesus. Many of them had their own gospels, and some produced large libraries. Thus, the New Testament turns out to be only a very small 


\section{Reading the Bible again with Borg}

selection of texts from a large body of literature produced by groups and communities during the first hundred years.

The gospels are foundational because they tell the story of Jesus. After having discovered the Jewishness of Jesus, as Den Heyer (1996:xiii) puts it, you read the stories with different eyes, because you then realize that Jesus did not live in a vacuum. The gospel stories are the product of a developing tradition, containing earlier and later layers of material and combining history remembered and history metaphorized (Borg 2002:186). They can be read for the sake of reconstructing the historical Jesus and they can be read as late first century documents that tell us about Christian perceptions and convictions about Jesus some forty to seventy years after his death (Borg 2002:190). One can thus meet the "historical Jesus" and the "canonical Jesus" in the gospels. Mack (1995:79) calls the "canonical Jesus" the Christ from the Christ myth and cult.

When no distinction is made between the historical Jesus and the canonical Jesus, confusion results. When what is said about the canonical Jesus is taken literally and historically, we lose track of the rich metaphorical meanings of the gospels. Borg (2002:191) sees the pre-Easter Jesus as a Jewish mystic, healer, teacher of unconventional wisdom, social prophet, and renewal-movement initiator. Easter is the experience among the followers of Jesus as a living reality after his death, and the conviction that God had exalted him to be both messiah and Lord. This Jesus is the canonical Jesus and is the one we meet in the New Testament.

The gospels, according to Borg (2002:192) are thematic constructions, each with its own distinctive themes, purpose, and emphasis. It is an aperture through which we are given an advance glimpse of the evangelist's perception of Jesus and his significance. Patterson (1998:222) however, views it differently. To him the gospels are the result of early Christian exegetical activities. The traditional Jewish literature and beliefs were studied and interpreted to give birth to the gospels. Is Borg saying the same, using different wording?

Modern readers of the Bible must still learn to distinguish between the historical Jesus and the kerygmatic Jesus. And the big challenge of our time is to learn that the historical Jesus is of no importance for our faith. We believe the reader has to understand the kerygmatic Jesus as a metaphor through which we see something of God.

\subsection{A Markan point of view}

Mark was written around $70 \mathrm{CE}$, the year in which Jerusalem and the temple were reconquered and destroyed by the Roman Empire. 
The impact of the war and its climax are very noticeable especially in the thirteenth chapter of Mark, also known as "the little apocalypse" (Borg $2002: 193)$. Mark viewed the events of 70 , the suffering during the final stages of the war, the destruction of Jerusalem and the temple, as signs that "the end" was at hand. The gospel has an apocalyptic eschatology.

"Apocalyptic eschatology appears earlier in his gospel as well, in a 'kingdom of God' saying. In the middle of Mark, immediately after a passage about the Son of Man coming in glory with his angels, the Jesus of Mark speaks of the imminence of the kingdom" (Borg 2002:194). The imminence of the kingdom is the theme of Jesus' brief inaugural address in Mark. The rest of the gospel deals with another major theme, namely "the way," referring to the "way" of following Jesus.

For Mark the "way" of Jesus is the path of death and resurrection. Repentance in Mark does not mean contrition for sin. Its meaning is rooted in the exile story. To repent is to return from exile. To repent is to embark on the journey of return, to enter the kingdom of God. "Thus, for Mark, the canonical Jesus calls his followers to the way of the cross, the path of death and resurrection. The way of Jesus - the way of repentance and return from exile - involves dying to an old way of being and being born into a new way of being. Taken literally, it is a path of martyrdom ... taken metaphorically, it refers to the internal process at the center of the way of Jesus and the life of discipleship" (Borg 2002:195).

According to Mack (1995:156) the gospel is a myth of origin for the Markan community. Mark used the notion of Jesus as a martyr for it fits his project of accounting for the troubled history of his group and the notion of the resurrection, linked to an apocalyptic finale, to project a future vindication for both his group and for Jesus. This means that the present time of trouble was survivable.

Mark, according to Mack (1995:157), thus created a story that combined the Jesus traditions with which he and his group were familiar, with the thought of Jesus as a martyr and so he transposed the Christ myth into a historical narrative. He used the old wisdom tale of the righteous man, wrongly accused, as a pattern for the sequence of episodes leading up to the trials and crucifixion of Jesus. And so the story was easily merged with the noble death pattern of the Greco-Roman martyrology. Who, Mack or Borg, found "the way" to best understand the text? Or do their viewpoints complement each other? 


\section{Reading the Bible again with Borg}

\subsection{Matthew's perspective differs}

Matthew was written about ten to twenty years later than Mark. Matthew, although the most Jewish gospel, is also the most hostile to Judaism. Matthew intensifies Jesus' criticism of the scribes and the Pharisees. "The intensity of the conflict with Judaism in Matthew reflects the situation of his community" (Borg 2002:196). After the Roman conquest the Jewish community began to ostracize Jews who followed Jesus as the messiah, claiming that they were no longer true Jews. Matthew for his part emphasized the continuity with Jewish tradition. He quoted the Hebrew Bible about forty times. He uses a Moses typology to construct his gospel. He arranged Jesus' teachings into five blocks, like the five books of the Pentateuch. He draws parallels between Jesus' and Moses' birth and life. Even Jesus' inaugural address reflects the Moses typology (Borg 2002:197). The sermon on the mountain is a typology of Mt Sinai. Thus to Matthew Jesus is one like Moses.

This is the way in which Matthew and his community told and understood the story of Jesus. For his community the gospel functioned like the Pentateuch, and Jesus was the fulfillment of the prophecy. He claimed that the traditions of Israel belonged to the Christians of his community, not to the scribes and Pharisees (Borg 2002:199). All that Mack (1995:164) added to this was that Jesus was not just like Moses, he was a teacher whose teachings were based on Moses' Torah, interpreted for the time in which he lived.

\subsection{Luke-Acts has its own interpretation}

Luke narrates Jesus' mission to the Jewish people in the Jewish homeland, and Acts describes the spread of early Christianity to the Roman Empire beyond the Jewish homeland (Borg 2002:199). These documents were written a decade or two after Mark.

Central to Luke is the theme of the Spirit of God. The Spirit descended upon Jesus at his baptism, it then led him to the wilderness. The Spirit was there when he began his public activity. When he died he commended his spirit into God's hand. And when he was resurrected he sent the Spirit upon his followers. Acts open with a twofold repetition of Jesus' promise of the Spirit. The gifts of other languages, the wind and fire, are all classic images for the Spirit. Thus, the same Spirit that conceived, empowered, and guided Jesus now does the same within the Christian community as it spreads from Jerusalem to Rome (Borg 2002:201). Thus, as Mack (1995:167) added, attention "was no longer fixed solely on Jesus, but interest had turned to focus on the apostles". 
Jesus' inaugural scene in Luke begins with him reading a passage from Isaiah about the Spirit-anointed prophet. As such it provides a summary of the theme of the rest of the gospel.

\subsection{John - yet another construct}

John differs from the Synoptics in chronology, geography, message and style. His discourses about Jesus are the richest in symbolic language in the New Testament. According to Borg (2002:204) in John metaphorical narrative dominates history remembered and historical memory.

In John, rather than the inaugural address found in the synoptics, we have an inaugural deed, namely the changing of water into wine at the wedding banquet. With this sign John is saying what he believes Jesus is all about. To him it is about a wedding banquet at which the wine never runs out and the best is saved for last (Borg 2002:205). As far as Mack is concerned (1995:176), the story started a few lines earlier, before the beginning of the world. Through a series of interlocking lines, the logos circles around, leaving in its wake created things, life, light, and finally mankind. Then the logos takes on the form of a human being, and there was Jesus.

Borg (2002:206-218) presents a few narratives which he believes are pure metaphorical narratives, having no historical event that lies behind it. These are for example: his walking on the water; feeding the multitude; restoring sight to the blind; and, Jesus as the Way. The meaning of these stories lies in the metaphor and not in the possible connection it may have with history.

Mack (1995:177) differs from Borg's understanding of the gospel in the sense that he interprets John's story not as a story about the historical Jesus or even about the Jesus of the synoptics. John's story, according to Mack, is about the manifestation of a god. John's Jesus appears from heaven, speaks only in self-referential terms, is the son from the Father, the bread of life, the water of life, and the way to the Father. Thus, altogether a different kind of being.

At the end of the story Jesus returns to the Father by dying, but not death as a martyr. As Mack (1995:182) puts it, the mythology of Jesus' death as martyrdom was set aside in favour of the myth of a god's appearance in the world and return to his heavenly abode. Another fact Mack (1995:183) added is that it is not always clear where the voice of Jesus ends and the voice of the Johannine community takes over. The "I" of the mythological Jesus, the light of the world, and the "I" of the Johannine Christian, the enlightened one who "abides in Jesus" and "in whom Jesus' words abide," 


\section{Reading the Bible again with Borg}

are, in the last analysis, one and the same for Mack. Quite a different picture to the one Borg painted?

The implication of reading and understanding the gospels in this way as opposed to the traditional way, not only has significance for one's reading of the Bible, but also for one's faith. It is upon realizing the differences between the Gospels and upon seeing the different Jesus pictures that one questions the traditional doctrine regarding the inspiration of the Canon. One questions the doctrine of the holy trinity, because suddenly Jesus seems to be a metaphor or a character that can be manipulated in a narrative to convey an ideological perspective. The gospel seems not to be only about sin, repentance and after-life. One begins also to see authors and congregations' self understanding, their interpretations of Jesus and their understanding and witnesses of God. One sees and reads it in a language, in metaphors and in a context that are worlds apart from one's own.

The practical implication is that we have to articulate our faith in God in our own tongue for own time. We too understand God in a specific way and experience God in a specific manner. It is not enough to merely keep on parroting the gospel narratives. Their language and direct speech do not speak to the modern reader in the same fashion it did to the first audience. We should move a step or two on.

\section{PAUL: A WHOLE NEW STORY}

1 Thessalonians, a letter from Paul dating back to the year $50 \mathrm{CE}$, is the earliest document of what eventually became the New Testament. He wrote more New Testament documents than anybody else and he, more than anybody else was responsible for the spread of the Jesus movement into the Gentile world (Borg 2002:227).

Seven of the letters in the New Testament are from Paul. They are, in chronological order, 1 Thessalonians, Galatians, 1 and 11 Corinthians, Philemon, Philippians, and Romans. All of these were most likely written in the 50's (Borg 2002:229). The book of Acts serves as a secondary source of information about Paul, as more than half of that document is about Paul. (Whether it is the "historical" Paul, I am not so sure.)

"The decisive event in Paul's life was his experience of the risen Christ on the road to Damascus. That experience transformed Paul" (Borg 2002:229). This happened about five years after Jesus' execution. On the road Paul had a vision. The vision blinded him. "Whether Ananias' restoration of sight to Paul is history remembered or metaphorical narrative, its metaphorical meaning is provocatively appropriate: filled with the Spirit, Paul 
saw anew as the scales fell from his eyes. Then he was baptized, and his life as an apostle of Jesus began" (Borg 2002:230).

Paul was deeply religious before Damascus. Also, he did not convert from one religion to another. He was converted within a tradition because he continued to regard himself a Jew after his conversion. But he was converted from one way of being Jewish to another way of being Jewish. This dramatic experience changed not only Paul, but eventually the world (Borg 2002:231). According to Mack (1995:102) Paul's conversion was a personal seeing that the Christ myth was true, that the Christian's claim about Jesus had significance for Israel's mission and that he had to lead the way.

According to Borg (2002:232) Paul's life before Damascus equipped him well for his vocation. He grew up in a Hellenistic city in the Diaspora. He was fluent in Greek and was thus at least bilingual. He was a Roman citizen by birth, and he was urban and cosmopolitan. Because he was a tentmaker, he was able to support himself everywhere, as he did in his life as missionary.

Paul was a Jewish Christ-mystic. A mystic is a particular type of religious personality. Mystics do not simply believe in God, they know God. They have direct, vivid, and typically frequent experiences of the sacred (Borg 2002:234). Paul regarded his mystical experience of Jesus as a resurrection experience (1 Cor 15). This happened in his mystical vision on the road to Damascus.

In Galatians he uses classical mystical language that points to his mystical identity, namely the death of an old self and the birth of a new self spoken of as Christ living in him (Borg 2002:236). His mystical experience was the source of everything he became as follower of Jesus. It was the foundation of his message (Borg 2002:237).

His life as a missionary lasted about twenty-five years and most of it was spent in Asia Minor and Greece. During the 50's he wrote most or all of his letters. His life as an apostle was often arduous, filled with controversy, and marked by suffering. He followed a consistent missionary strategy. When he arrived in a city, he began by going to the synagogue. He preached and his converts would then begin a community life of their own, gathering regularly for worship and instruction and life together. They gathered in houses or villas. When they were an established community, Paul moved on to a new city (Borg 2002:239).

Paul's letters were an integral part of his life as an apostle and community-founder. He kept in touch with his communities after he moved on through his letters. The letters were, according to Borg (2002:240) not intended for silent reading by individuals, but were addressed to the community, which as a whole heard them. The letters were "conversations in 


\section{Reading the Bible again with Borg}

context." A letter was not a summary of his message, but was rather a response to a letter he had received.

\subsection{Paul's ideological construction}

Paul knew Jesus as the messiah. He knew about his subversive wisdom, his healings, his passion for social justice for the poor and marginalized, his indictment of the domination system and his goodness (Borg 2002:242). The central meaning of Paul's experience of the risen Christ was "Jesus is Lord." To him it means that Jesus lives and that he is Lord. These were immediate inferences from his Damascus Road experience.

Thus for Paul the resurrection of Jesus was not primarily about an afterlife through the defeat of death. Nor was its central meaning that we also will be raised someday; ... Rather, Easter meant, in an affirmation that Paul shared with the Jesus movement as a whole, "Jesus is Lord".

(Borg 2002:243)

To Paul "Christ" was like a second name for Jesus.

The connection between Jesus' resurrection, his status as Lord, and the cosmic extent of his lordship is magnificently made in a passage from Paul's letter to the Phillippians that is probably based on a pre-Pauline hymn of praise. Immediately after it speaks of the death of Jesus, it affirms that God "exalted" Jesus, which means "raised up"; and it then speaks of Jesus' dominion as Lord as extending through all three levels of the three-story universe of the ancient worldview.

(Borg 2002:244)

For Mack (1995:146) this hymn expresses the desire for the Greek notion of mimesis. It is an example to imitate.

Calling Jesus "Lord" had both religious and sociopolitical meaning. "Jesus is Lord" meant "Caesar is not Lord." By calling Jesus "Lord" both our religious and our political loyalties are being claimed.

The metaphor "in Christ" is an important phrase for Paul's vision of the Christian life (Borg 2002:245). Paul is a dialectic thinker. He often thinks in contrasts or oppositions. The opposite of life "in Christ" is life "in Adam." Life "in Adam" is a metaphor for the human condition. This is a life of separation or estrangement from God. It is also life of sin and death. Under the dominion of sin, we are not free. It is thus a life of bondage and internal conflict (Borg 2002:246). "In Christ" is the opposite. It means to be free, to no longer be 
enslaved to the dominion of sin and death and to be reconciled with God. It thus brings the end of exile. It is to live in the presence of God and to be a new creation (Borg 2002:247). But how does one move from a life "in Adam" to a life "in Christ?" For Paul, the new way of life is created by God through Christ (Borg 2002:248). He said: "It is no longer I who live, but Christ who lives in me." To be baptized symbolizes and ritually embodies dying to an old way of living and being resurrected into a new way of life. The way that we become "in Christ" is by dying and rising with Christ, by participating in the path of death and resurrection (Borg 2002:250).

Paul's other metaphor for speaking of the Christian life is drawn from the legal world namely "justification by grace." The basis for being found in the right by God is grace, not law; faith, not works. Justification is a gift, not a reward (Borg 2002:252).

Justification by grace is about the basis of our relationship with God in the present. It is about becoming conscious of and entering more deeply into an already existing relationship with God as known in Jesus. It is not about meeting requirements for salvation later but about newness of life in the present (Borg 2002:255).

For Paul the death of Jesus was utterly central. He wrote to the community in Corinth: "I decided to know nothing among you except Jesus Christ and him crucified," and, even more compactly he wrote, "we proclaim Christ crucified." It is a historical fact that Jesus was crucified. On the other hand, according to Borg (2002:256) Paul invests this historical fact with a wide range of symbolic meaning that goes far beyond a historical assertion. For Paul, "Christ crucified" is an indictment of the imperial system of domination that executed Jesus. And the resurrection was God's yes to Jesus and God's no to the domination system (Borg 2002:256). "Christ crucified" is also the revelation of God's love for us. It is also a symbol of the path of transformation (Borg 2002:257).

Mack (1995:123) sees Paul quite differently. According to him, we have learned three things from Paul. The first is that he understood the logic at the heart of the Christ myth as a mythology aimed at justifying a mixed congregation of Jews and gentiles as the children of the God of Israel. The second is that Paul's Jewish mentality determined every new construction he put upon it, and thirdly, we have learned that Paul's gospel was his very own construction. It was not the way the others in the Jesus movement of the congregations of the Christ understood the import of Jesus and God's plan for a kingdom. 


\section{Reading the Bible again with Borg}

\section{INDEED A REVELATION}

A substantial percentage of fundamentalists and conservative-evangelical Christians read Revelation as forecasting the imminent "end of the world" and the second coming of Christ (Borg 2002:265). It was not the last written document of the New Testament, nor did its author know that it would someday conclude the Christian Bible (Borg 2002:266).

The book of Revelation is an apocalypse. "Revelation" and "apocalypse" are synonyms. It means to "unveil" or to "disclose," but also denotes a type of literature. "As a literary genre, an apocalypse is defined by both content and style. Its subject matter is one or more visions disclosing or unveiling either the future or the heavenly world or both. Commonly, the present age is seen to be under the evil powers who will soon be overthrown and destroyed by God, ushering in an age of blessedness for the faithful" (Borg 2002:268). Revelation was written near the end of the rule of the Roman emperor Domitian around the year $95 \mathrm{CE}$.

There are two ways of reading Revelations. The one is a futurist reading. This means that Revelation tells us about what will happen some time in the future (Borg 2002:273). And then there is the past-historical interpretation.

The past-historical reading, which grows out of the belief that we understand the message of Revelation only by setting the text in the historical context in which it was written, emphasizes what Revelation would have meant in the past. In this reading, Revelation tells us what the author believed would happen in his time. This approach takes seriously that the visions of Revelation are found in a letter addressed to specific Christian communities in Asia Minor late in the first century. As such, the text was meant to be a message to them, not a message to people thousands of years later.

(Borg 2002:276)

John, according to Mack (1995:195) was worried about false teachings and persecution. The churches were not behaving properly and John wrote a warning to them that they should repent, rekindle their original fervor, and learn to wait patiently for their rewards.

But for Borg Revelation is more than mere history or mistaken prediction. The book has power. Its numinous language about God and Christ has been integrated into Christian worship, liturgy, and art (Borg 2002:279).

The central conflict in the book is the conflict between competing lordships: Christ's and Caesar's. John proclaims the exclusive lordship of God 
and "the Lamb" as known in Jesus (Borg 2002:280). Among the reasons for the power of the Apocalypse is John's use of one of humankind's most widespread archetypal stories, namely the ancient cosmic combat myth (Borg 2002:281). This cosmic combat myth appears in many cultures, ancient and modern, and takes on many forms. It is found in Enuma Elish, Psalm 74, Job, the death and resurrection of Jesus, St George slaying the dragon, and the archangel Michael warring with the dragon. In our time this myth forms the central plot element of the Star Wars movies (Borg 2002:282).

John reverses the Roman Empire's version of the story of Apollo and Python. Both Caesar Augustus and Nero styled themselves as Apollo, son of a god, who brought in a golden age of order and peace by slaying the Python. John echoes this story when he tells about the war in heaven and the dragon's defeat as an event that happened on earth. He thereby states that Jesus, and not Caesar, is Apollo, the light of the world (Borg 2002:284). John depicts Rome as the incarnation of the dragon. Rome at that stage was the "domination system." Rome controlled the world. In another chapter, John personifies Rome as "the great whore." Rome is the opposite of the kingdom of God as disclosed in Jesus. Mack (1995:196) calls John's imagery a veritable hodgepodge of ancient Near Eastern myths.

The climax of the Apocalypse is a vision of a city of a different kind altogether. "After John's vision of Babylon the Great and its fall, he sees 'a new heaven and a new earth' and 'the New Jerusalem' descending out of the sky ... Revelation is thus the tale of two cities: one city comes from the abyss, the other from God" (Borg 2002:289).

Thus, John's vision has historical elements. His vision is perhaps best understood as "dream of God." God's dream for humankind. It is a dream for this earth (Borg 2002:291). It speaks of the reunion of God with humankind. A city in which the tree of life is and through which the river of live flows. There we will see God (Borg 2002:292).

The dimension that Mack (1995:197) brings along in his interpretation is that John's revelation is an example of cultivating the image of martyrdom as the major metaphor for making sense of a difficult set of circumstances. Thus he raised the metaphor of martyrdom to mythic status in order to imagine the ultimate vindication of the truth of the Christian faith. From that time onward, the true confessor of the Christian faith would be the martyr for Christ.

The implication of a new way of reading Revelations is that many missionaries' and churches' total raison d'être falls apart. Many of them use fear for the end times, fear for the devil et cetera to motivate people to repent and to live a life that will be rewarded. However by reading Revelations in 


\section{Reading the Bible again with Borg}

context and against a Roman-Jewish background opens up a whole new picture.

\section{EPILOGUE}

The Bible speaks with more than one voice. It contains different voices of what life with God is about. The major voices of the biblical tradition have three primary convictions in common. According to Borg (2002:299-300) it is:

- $\quad$ Firstly, a deep sense of the reality of the sacred. God is not only real, but knowable, not in a set of statements, but experientially as a Mystery beyond all language.

- $\quad$ Secondly, there is a strong conviction that our lives are made "whole" and "right" by living in a conscious relationship with the Mystery who is God alone. Christian faith is about faithfulness and fidelity to this relationship. This relationship is the path of personal transformation. It involves dying to an old way of being and being born into a new way of being.

- $\quad$ Thirdly, these voices are convinced that God is a God of justice and compassion. God's passion is the ground of a biblical ethic centered in justice and compassion. Justice means asking why there are so many victims and then doing something about it.

From these three core elements flows a remarkably simple vision of the Christian life. It is crystallized in the very familiar twofold "great commandment" attributed to Jesus (Borg 2002:301). Judaism and Christianity share this elemental core.

Being Christian means living within Christian community's scripture, stories, songs, rituals, and practices. The Christian community nourishes the alternative life of centering in God and instills a passion for compassion and justice for the whole creation. The Bible has a central role, perhaps second only to that of the Spirit. As the foundation of the Christian tradition, the Bible is the source of our images and stories for speaking of God's passion.

Through and within the Bible's many voices, we are called to discern the voice that addresses us in our time. And listen: what we hear matters greatly. It makes all the difference (Borg 2002:302).

Thus, a new reading of the Bible brings with it a fresh approach to Christianity and a new way of being a Christian. It also opens one's eyes to the churches kerygma. The implication for the Christian is that one must no longer put one's trust upon assertions of faith, dogmas, confessions, ideologies and theologies, but one should rather base one's trust upon the 
cause of faith. It means, as Van Aarde (2001:149) said, that God and not the Bible is the primary authority. The books of the Bible are not the Canon. The cause of Jesus (Sache Jesu) is the Canon and that is God's becoming event in Jesus of Nazareth. He is the manifestation of God, the observable face of God. His cause is God's presence for us (Van Aarde 2001:150).

This means that we must live in a relationship with God self, not with Jesus of the Bible. Jesus and the Bible are the fingers that point. Like everything else in creation, they point to God, the One in whom to put one's ultimate trust.

\section{Works consulted}

Adriaanse, $\mathrm{H} \mathrm{J}$ 1998. Canonicity and the problem of the golden mean, in Van der Kooij \& Van der Toorn 1998:313-330.

Borg, M J 2002. Reading the Bible again for the first time: Taking the Bible seriously but not literally. San Francisco, CA: HarperSan Francisco.

Crossan, J D 1995. Jesus: A revolutionary biography. New York, NY: HarperSan Francisco.

Goody, J 1998. Canonization in oral and literate cultures, in Van der Kooij \& Van der Toorn 1998:3-16.

Mack, B L 1995. Who wrote the New Testament? The making of the Christian myth. San Francisco, CA: HarperSan Francisco.

Patterson, S J 1998. The God of Jesus. Harrisburg, PA: Trinity Press International.

Van Aarde, A G 2001. The "cause of Jesus" (Sache Jesu) as the Canon behind the Canon. HTS 57 (1\&2), 148-171.

Van der Kooij, A \& Van der Toorn, K (eds) 1998. Canonization and decanonization. Papers presented to the International Conference of the Leiden Institute for the Study of Religion (LISOR) held at Leiden 9-10 January 1997. Leiden: Brill. (Studies in the History of Religions 82.)

Woods, C J 1996. Congregational Megatrends. New York, NY: Alban Institute. 